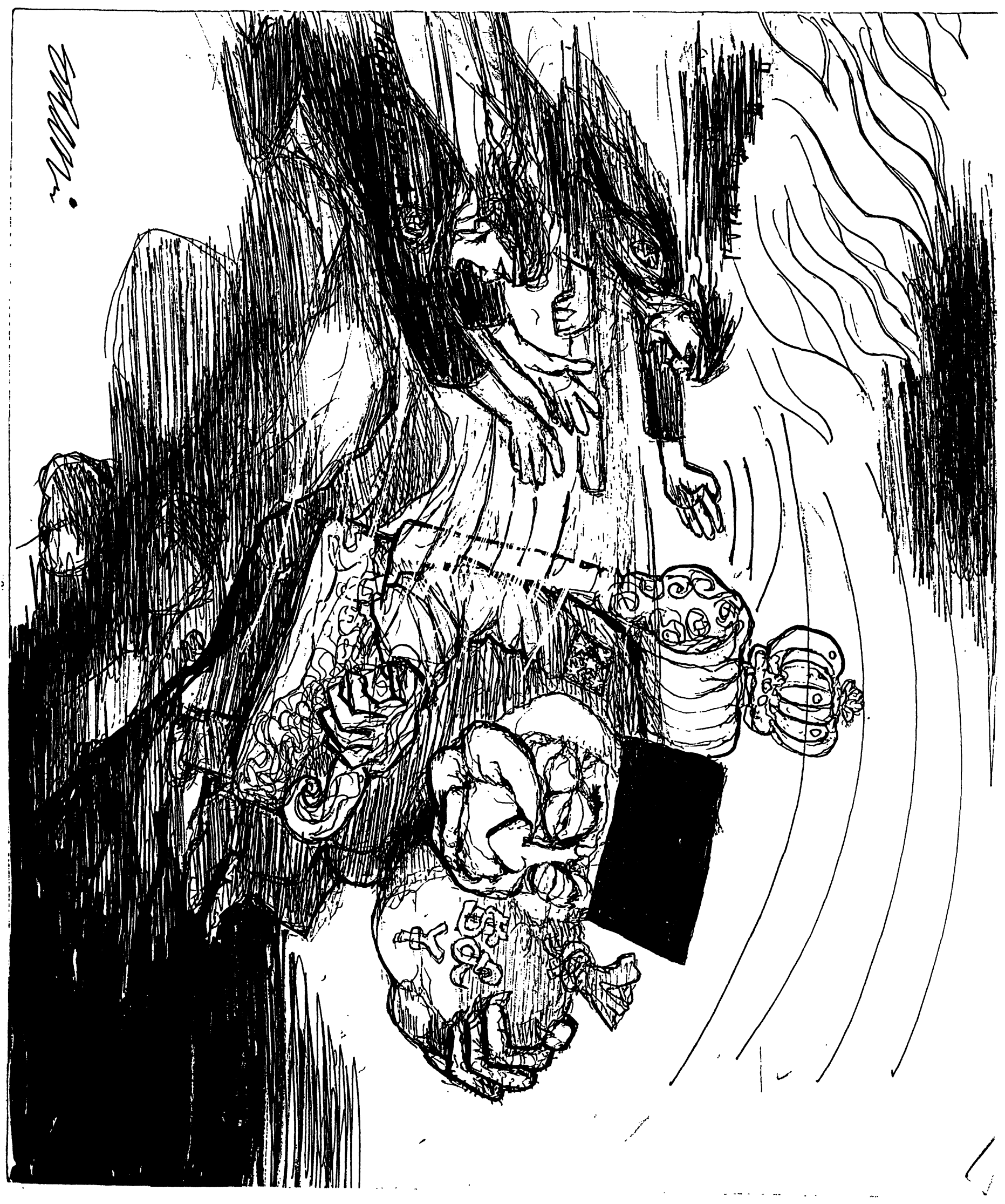




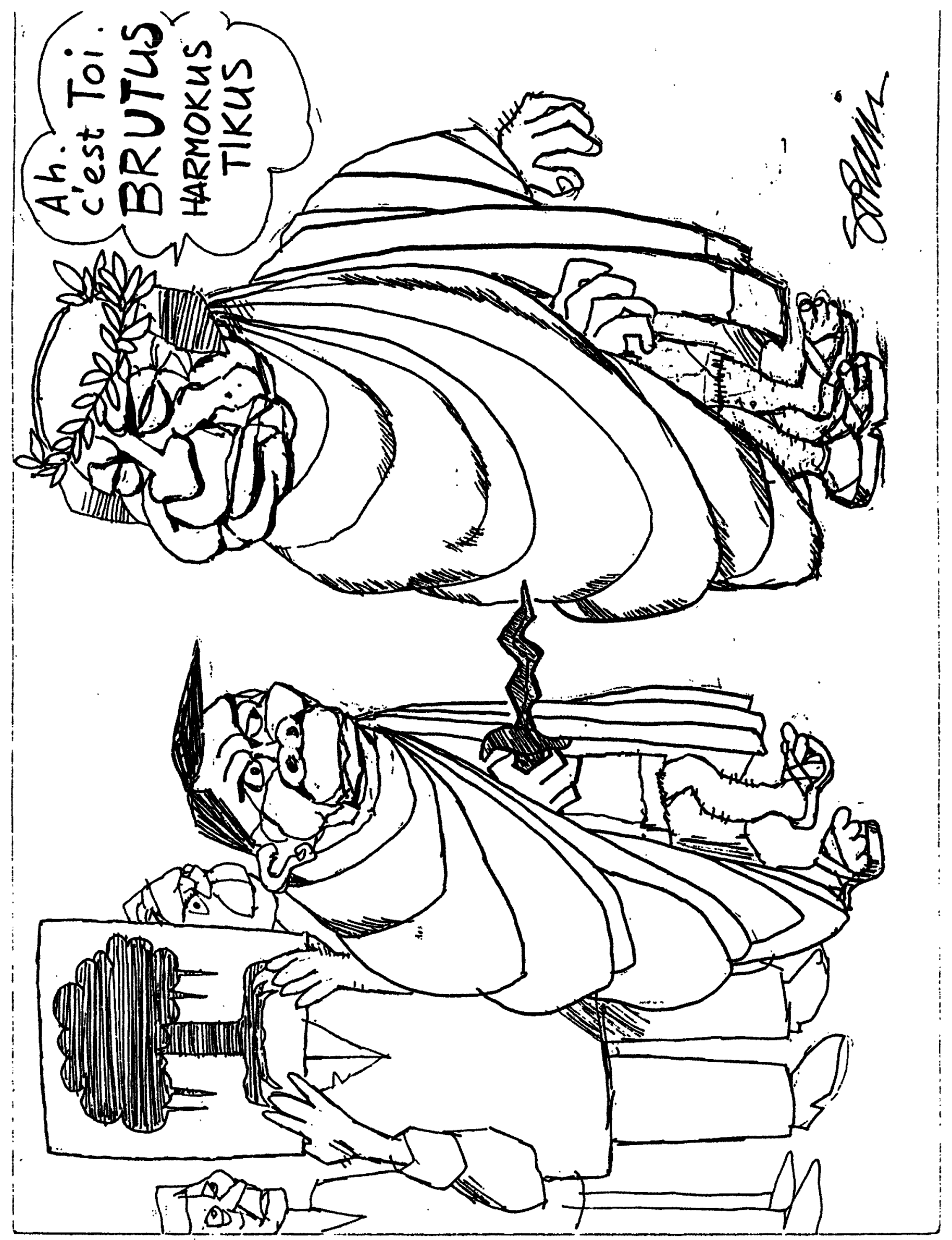




\title{
RAWAN IS AS RAWAN DOES: THE ORIGINS OF DISORDER IN NEW ORDER ACEH
}

\author{
Geoffrey Robinson
}

\section{Introduction}

Despite its best efforts to provide a congenial environment for foreign investment and domestic corruption, over thirty-odd years the New Order regime confronted scenes of increasing chaos, violence, and political disintegration from Sabang in the west to Merauke in the east. The problem was especially acute in Aceh, Irian Jaya, and East Timor-the three regions designated by the authorities as daerah rawan or "trouble spots" for much of the last two decades. In each of these regions the government faced significant demands for greater autonomy or independence spearheaded by armed political movements. ${ }^{1}$ The regime met each of these challenges with massive military operations, in the course of which hundreds of thousands of people were killed. As though to justify the harshness of its approach, the government referred to the resistance movements as Gerakan Pengacau Keamanan (GPK) or "Security Disruptor Movements."

In the view of New Order ideologues-and a good number of foreign experts -these independence movements were somehow a natural if regrettable consequence of the ethnic, linguistic, and geographic heterogeneity of the country. In a country so diverse, the argument ran, the primordial sentiments of diverse population groups and the traditions of enmity among them pushed inexorably in the direction of disintegration. The continued integrity and unity of Indonesia, it followed, depended

1 These were: The Acheh-Sumatra National Liberation Front, or Aceh Merdeka in Aceh, the Organisasi Papua Merdeka (OPM) in Irian Jaya, and in East Timor, the Frente Revolucionaria Timor Leste Independente (Fretilin), and more recently, the Conselho Nacional da Resistência Timorense or CNRT. 
ultimately on the toughness of the central state; on its capacity and willingness to use force against those who would challenge it. In this view, moreover, the experience of the 1940s and 1950s had proved that a soft, democratic, or federal state would eventually lead to the break-up of the country, along the lines of former Yugoslavia or the former Soviet Union.

My principal aim in this paper is to consider the merits of these views by examining the evidence from Aceh, where an estimated two thousand people were killed-and countless others were arbitrarily detained, tortured, and raped-after 1989 when government troops began a campaign to crush the armed independence movement, Aceh Merdeka. The inquiry is guided by two questions. First, why was Aceh so intractably unsettled, so rawan, in the final decade of the New Order? And second, is it destined to remain that way in the post-Suharto era? The evidence presented in this paper suggests that the problems in Aceh were not the inevitable result of the region's cultural, religious, or other primordial differences with other parts of the country, nor of its often noted "tradition" of resistance to outside authority. It also shows that, far from being the last bastion against national disunity and instability all these years, the New Order regime itself was largely responsible for the serious and protracted violence in Aceh. Accordingly, I argue that the demise of the New Order state, and its replacement by a less authoritarian, less militaristic, less centralized variant, could bring a swift end to the unsettled conditions that have plagued Aceh in recent years.

This is not to say that issues of culture and tradition were of no consequence in producing unsettled conditions in Aceh. Unquestionably they were, as the first section of the paper attempts to show. Nevertheless, I hope it will become clear that, at best, these factors provide only a partial explanation of the problem. They do not satisfactorily explain how or why the challenge from Aceh Merdeka-which was minuscule when it surfaced in 1976 and again in 1989-degenerated into widespread violence, and produced the deep-seated bitterness toward the regime that had become the norm by 1998. Nor do they explain why serious political violence, including political killings, suddenly resumed in late 1998. My argument is that two areas of New Order policy and practice were of special importance in producing these outcomes. First, its approach to the exploitation of natural resources and the distribution of the benefits; and second, the doctrine and practice of its armed forces. The New Order regime's actions in each of these realms produced a legacy of deep mistrust and animosity toward the central government, which survived the demise of President Suharto in May 1998 and appeared likely to inhibit a return to peace. To make matters worse, President Habibie seemed inclined to pursue the same policies and actions in Aceh as his predecessor, thereby accentuating rather than alleviating the underlying causes of unrest. Nevertheless, I argue that because the New Order regime's behavior in both of these spheres was shaped by underlying historical conditions, changes in those conditions are likely to alter significantly the patterns of violence and instability in the future.

While Aceh is in some respects a unique case, the argument advanced here may help to explain the growth and persistence of "trouble" in other regions as well. The fit is especially good for Irian Jaya. Despite fundamental differences in culture, religion, ethnicity, and political history, the pattern of resistance and protracted conflict there 
appears to be rooted in the same basic features of the New Order state that drove Aceh to a condition of chronic violence after 1989. And while the conflict in East Timor unquestionably has its own political and historical dynamic, I think the arguments made in this paper may help to illuminate certain dimensions of that struggle as well.

\section{History and Rebellion}

Aceh has long been described as a center of resistance to outside authority, and a region with a strong Islamic tradition. That reputation was firmly established during the thirty-year Aceh War (1873-1903) in which an assortment of armed Acehnese bands, mobilized increasingly by Islamic leaders and inspired by the view that they were fighting a holy war, sought to resist the imposition of Dutch rule. In part because of the overwhelming military force deployed by the Dutch, but also because of the willing collaboration of many Acehnese aristocrats, known as uleebalang, colonial forces eventually prevailed. Yet while the conflict officially ended in 1903, sporadic opposition to Dutch rule continued for much of the next forty years.

The traditions of political resistance and Islamic identity were further reinforced during the Japanese occupation of the Indies from 1942 to 1945, and in the period of National Revolution (1945-1949) that followed. ${ }^{2}$ As in other parts of the archipelago, the occupation helped to invigorate an emerging consciousness of anti-colonial, Indonesian nationalism in Aceh while providing unprecedented opportunities for political mobilization, especially among the youth and reformist Islamic groups. One consequence of these developments was that, in the period after the Japanese surrender in August 1945, these groups emerged as strongly pro-Republican, raising substantial amounts of money for the fight against the returning Dutch. Equally important, the vacuum of power created by the Japanese surrender unleashed a form of anti-feudal social revolution in Aceh, in which an alliance of militant youth and Islamic organizations came close to annihilating the aristocratic uleebalang class. In contrast to other parts of the Indies, moreover, Aceh was never reoccupied by Dutch or other Allied forces, so that the social revolution was never reversed, and the revolutionary forces were able to attain an unusual degree of political, economic, and military autonomy. ${ }^{3}$ Thus, when Indonesia finally gained its independence in late 1949 , the alliance that had staged the social revolution in Aceh emerged as the most powerful political and military force there.

Aceh's reputation for restiveness and Islamic militancy was further solidified in 1953, when its leaders joined groups in other parts of Indonesia in a decade-long rebellion which sought the creation of a Negara Islam Indonesia (Islamic State of

\footnotetext{
${ }^{2}$ On Aceh during the National Revolution see: Anthony Reid, The Blood of the People: Revolution and the End of Traditional Rule in Northerm Sumatra (Kuala Lumpur: Oxford University Press, 1979); and Eric Morris, "Aceh: Social Revolution and the Islamic Vision," in Regional Dynamics of the Indonesian Revolution, ed. Audrey R. Kahin (Honolulu: University of Hawaii Press, 1985), pp. 83-110.

${ }^{3}$ Christie writes that, by the late 1940s, "Aceh had its own military force under the command of Daud Beureueh; equally, it had its own trading links-developed in the chaotic revolutionary period-that were independent of central government control.... [By 1949] Aceh had become accustomed to a situation where it had considerable scope for autonomous action." Clive J. Christie, A Modern History of Southeast Asia: Decolonization, Nationalism and Separatism (London: I.B. Tauris, 1996), pp. 147-48.
} 
Indonesia).4 Aceh's so-called Darul Islam rebellion, nominally led by Teungku Daud Beureueh, was finally brought to an end in 1962 after years of complex negotiations, and low-level fighting, between Acehnese and central government authorities. While the rebellion failed to achieve its original goal of establishing an Islamic state in Aceh, it did win the province recognition as a Daerah Istimewa (Special Region) with nominal autonomy in the realms of religion, culture, and education. ${ }^{5}$ The resolution of the Darul Islam rebellion through negotiation, and with minimal loss of life, was eased significantly by the fact that, notwithstanding their dissatisfaction with the central government in Jakarta, the rebel leaders never sought to separate from Indonesia. They had joined the movement for Negara Islam Indonesia because they were opposed to the centralizing tendencies of the regime, and to what they saw as its softness toward the Indonesian Communist Party (PKI), but there was never any serious doubt about their loyalty to a united Indonesia.

The clearest evidence of this claim is that, for roughly fifteen years after the surrender of Teungku Daud Beureueh, the province of Aceh posed no special political or security problems to the central government. Indeed, its formerly rebellious political and religious leaders joined enthusiastically with the Indonesian armed forces, political parties and religious organizations, in destroying the PKI in 1965-66.6 And while central government authorities were somewhat anxious about the electoral successes of the Islamic oriented United Development Party (PPP) and the corresponding weakness of government party Golkar in the 1970s, there was little doubt that the vast majority of Acehnese continued to see themselves as loyal citizens of a united Indonesia. ${ }^{7}$

Then in late 1976 a new rebel movement, known as Aceh Merdeka, burst onto the scene. In marked contrast to Darul Islam, the leaders of Aceh Merdeka called explicitly for the creation of an independent state of "Acheh-Sumatra," and characterized the New Order as a regime of "Javanese imperialists."8 The movement gained strong early support in the Tiro district of Pidie, the home territory of its leader Teungku Hasan di Tiro, and on December 4, 1976 it unilaterally declared independence. The Indonesian government responded with a reasonably successful military operation aimed at capturing the movement's leaders, and in 1979 Hasan di Tiro, who had been living abroad from the early 1950 s to 1976 , left the country again to form a government in

\footnotetext{
4 The rebellion in Aceh was set in motion with a proclamation, dated September 21, 1953, declaring Aceh to be part of the Negara Islam Indonesia. Mr. S. M. Amin, "Sejenak Meninjau Aceh, Serambi Mekkah," in Bunga Rampai tentang Aceh, ed. Ismail Suny (Jakarta: Bhratara Karya Aksara, 1980), p. 80.

5 Aceh's special status is enshrined in Republic of Indonesia, Law No.5/1974 on the Principles of Regional Government Administration.

6 Tim Kell, The Roots of Acehnese Rebellion (Ithaca, NY: Cornell Modern Indonesia Project, 1995), p. 28.

7 The PPP defeated Golkar in Aceh in the elections of 1977 and 1982, but Golkar bounced back with convincing victories in the elections of 1987 and 1992. See Dwight King and M. Ryaas Rasjid, "The Golkar Landslide in the 1987 Indonesian Elections: The Case of Aceh," Asian Survey 28, 9 (September 1988): 916925.

${ }^{8}$ For a brief account of this early manifestation of Aceh Merdeka, see Nazaruddin Sjamsuddin, "Issues and politics of regionalism in Indonesia: Evaluating the Acehnese experience," in Armed Separatism in Southeast Asia, ed. Lim Joo-Jock and Vani S. (Singapore: ISEAS, 1984), pp. 111-128.
} 
exile. By 1982 Aceh Merdeka appeared to have been crushed, with most of its leaders either killed, in exile, or in prison. ${ }^{9}$

Nevertheless, the movement resurfaced in early 1989 launching a series of armed attacks on local military and police posts. Government authorities initially dismissed the attacks as the work of a minor criminal band with only a few weapons and little popular support. By mid-1990, however, it appeared that the rebels had gained the sympathy of a fairly wide cross-section of the population, especially in Pidie, Aceh Utara, and Aceh Timur. Moreover, civilians were now among the targets of the group's assaults, and government sources estimated that it had mobilized roughly two hundred armed fighters, some of whom were said to have received military training in Libya. ${ }^{10}$ After an apparently unsuccessful territorial operation against the movement, in mid-1990 the Regional Military Commander was replaced and some six thousand additional troops were deployed to the region, bringing the total to about twelve thousand. ${ }^{11}$ By late 1991 it appeared that government troops had largely succeeded in crushing the rebellion, and in killing most of its top leaders, but Aceh Merdeka supporters continued to menace Indonesian forces thereafter. One measure of the uncertainty of the central government's victory was that the military's Operasi Jaring Merah (Operation Red Net) remained in effect, and Aceh continued to be designated a Daerah Operasi Militer (DOM, Military Operations Area) until 1998.12

The sudden resumption of serious political violence in late 1998, just a few months after the withdrawal of most combat troops, was a further reminder of that uncertainty. On December 20, a crowd of about one thousand attacked a police post in Bayu, Aceh Utara, after hearing rumors that a police sergeant had sexually harassed a married woman. In the ensuing fracas, the officer in question narrowly escaped with his life, several government buildings were destroyed, an army officer and his wife were badly beaten, two marines were kidnapped, and at least two civilians suffered serious injury. Just over a week later, on December 29, a crowd in Lhok Nibung, Aceh Timur, beat to death several soldiers whom they had dragged from a passing bus. On January 3, 1999 a military operation called Operasi Wibawa 99, ostensibly aimed at capturing those responsible for the killings, and restoring government authority, resulted in scores of arrests and the killing of at least eleven people in the vicinity of

${ }^{9}$ Political trials of suspected Aceh Merdeka supporters continued into 1984. Kell, The Roots of Acehnese Rebellion, p. 66.

${ }^{10}$ From early 1989 to April 1990 Aceh Merdeka attacks left only one civilian victim. By the end of June 1990, however, at least thirty civilians, many of them transmigrants, had been killed in attacks attributed to the group. Amnesty International, Shock Therapy: Restoring Order in Aceh, 1989-1993 (London: Amnesty International, 1993), pp. 8-9.

11 The President issued the order for troop deployments on July 6, 1990, and further reinforcements arrived in early August 1990. The troops deployed from outside the region included two battalions of the elite Kopassus (Special Forces Command), as well as units of the Marinir Jakarta, Kujang Bandung, KODAM VII/Brawijaya, Arhanud Medan, Linud Medan and Police Mobile Brigades. For additional details, see Lembaga Bantuan Hukum, Laporan Observasi Lapangan di Propinsi Daerah Istimewa Aceh (Jakarta: December 1990), pp. 34-35. Also see Reuter, July 22, 1990; August 15, 1990; and November 25, 1990.

12 Armed Forces commander, General Wiranto, announced in early August 1998 that the DOM would be lifted in Aceh, and that all non-organic troops would be withdrawn as soon as possible. Kompas, August 11 1998. Roughly nine hundred combat troops, most of them from Kopassus and Kostrad units, were withdrawn from the area during the month of August. Kompas, September 1, 1998; $D \& R$, August 29, 1998. 
Lhokseumawe. Although there was doubt about who had led the assaults against military and police personnel, government authorities were quick to blame Aceh Merdeka, claiming that some of the group's leaders had returned from exile in Malaysia to resume their campaign for independence. Based on that interpretation, military authorities deployed several hundred combat troops in the area, and began what many feared would be another major counter-insurgency campaign. ${ }^{13}$

\section{The Limits of Tradition}

So legendary is Aceh's reputation for rebelliousness and Islamic militancy, that it is tempting to view the recent Aceh Merdeka uprisings as new manifestations of an Acehnese tradition or, as some would have it, an expression of a primordial Acehnese urge to independence. There is an element of truth in these views, as the patterns of historical continuity among the different rebellions attest. The geographical base area of Acehnese resistance, for example, has remained more or less constant over the past one hundred years or so. The center of all three uprisings has been in the north-eastern coastal areas of Pidie, Aceh Utara, and Aceh Timur. There has also been a measure of continuity in the social composition of the leadership of rebellion. Aceh Merdeka leader, Teungku Hasan di Tiro, for instance, is the grandson of a hero of the Aceh War, Teungku Cik di Tiro, and was an associate of Darul Islam leader, Teungku Daud Beureueh. ${ }^{14}$

These historical and personal links have given Aceh Merdeka an almost automatic credibility and meaning that is difficult to distinguish from the idea of "tradition." The experience and memory of previous rebellions has also helped to consolidate a myth about Aceh-as a unique center of Islamic tradition, as a region with a glorious history of independence and resistance to outside authority, and so on-that has instilled in both leaders and followers a sense of belonging to a political community, and has given resonance to calls for Acehnese liberation and national independence. These elements of historical continuity and shared memory are an important part of the Aceh Merdeka story. Indeed, it is fair to say that without them, it would be difficult to account for the rise and popularity of the movement in the 1970s and 1980s. One might even argue that in the absence of the presumed "tradition" of Acehnese resistance, New Order authorities would have paid far less attention to the movement.

Nevertheless, the description of the recent troubles in Aceh as a mere extension of a tradition of resistance and Islamic militancy arguably obscures as much as it reveals. It obscures, first, significant differences in the aims of the different rebellions. Whereas the Darul Islam rebellion and the Aceh War aimed sincerely to promote and protect Islamic law and culture, Aceh Merdeka focused squarely on demands for political and

\footnotetext{
13 Human Rights Watch, "International Effort Needed on Aceh," January 4, 1999; Amnesty International, "Renewed Violence Plunges Aceh Back into Terror," January 11, 1999; Meunasah, December 23, 1998, December 30, 1998, and January 5, 1999; Serambi Indonesia, December 22, 1998; and New York Times, January 5, 1999.

14 Hasan di Tiro, who was working for the Indonesian government at the United Nations in New York when the rebellion broke out in 1953, resigned from his post and designated himself Darul Islam's "ambassador" to the United Nations. Sjamsuddin, "Issues and politics of regionalism," p. 115.
} 
economic independence, with religious concerns mentioned only in passing. ${ }^{15}$ This explicit demand for independence was arguably not so much an extension of Acehnese tradition as a conscious emulation-despite the very different historical and legal circumstances - of the impressive independence movement that had emerged only a few years before in East Timor. Living outside of Indonesia, and circulating in the eddies and backwaters of the international diplomatic scene, Aceh Merdeka leader Hasan di Tiro was apparently inspired by, and perhaps envious of, the power and political appeal of the East Timorese resistance, and sought for a time to coax its spokesman, José Ramos-Horta, into an alliance. Though that initiative was rebuffed, di Tiro did his best to imitate the East Timorese resistance, in rhetoric and in method. The explicit demand for independence and the bellicose language and tactics he employed, were seen as a clear provocation by the New Order and triggered a predictably harsh response.

The focus on tradition and continuity also obscures important differences in the social composition of the leaderships of the different rebellions. Whereas the earlier uprisings were led, or very strongly supported by, Aceh's ulama, the leadership of Aceh Merdeka has been drawn predominantly from a collection of intellectuals, local government officials, disgruntled members of the armed forces, and local businessmen. Although he uses the title "Teungku," reserved for respected men of Islam, Hasan di Tiro cannot by any reasonable measure be described as a religious leader. Indeed, as those who have met him or read his political tracts generally concur, he is far closer, sociologically and politically, to the Acehnese aristocratic uleebalang class than to the ulama who led the earlier rebellions. He has, moreover, spent much of the past fifty years living abroad, first in the United States and then in Sweden, and in a fashion that one would not readily associate with the life of an Islamic scholar. It is hardly surprising, therefore, that very few ulama have given the movement their wholehearted support and some, including former supporters of Darul Islam, have been openly opposed to it. ${ }^{16}$

Finally, the focus on tradition and continuity obscures the long periods during which Aceh has been either super-loyal to the central Indonesian government, as it was from 1945 to 1949 , or politically calm and orderly, as it was through most of the 1960s and 1970s, and even much of the 1980s. These periods of calm and order make a nonsense of the idea that Aceh has been driven to rebellion by "natural" or "primordial" urges.

Taken together, these considerations suggest that the recent Aceh Merdeka uprisings, and the extreme violence that followed from them, cannot properly be understood solely as the continuation of a tradition. Indeed, the differences between the aims and the leadership of Aceh Merdeka and the earlier rebellions, and the onagain off-again pattern of political trouble in Aceh, both suggest that the rise of Aceh Merdeka and the extreme violence after 1989 were related to changes in the broader economic and political environment-an environment which changed quite dramatically during these years.

15 On this point, and for an overview of the ideas of Aceh Merdeka leader Teungku Hasan di Tiro, see Kell, The Roots of Acehnese Rebellion, pp. 61-66.

${ }^{16}$ Ibid., p. 65. 
134 Geoffrey Robinson

\section{The Political Economy of Violence}

Aceh's historical resistance to outside authorities has always been rooted, to some degree, in conflicts over the control and distribution of economic resources. Its conflict with the Dutch in the nineteenth century, and earlier with the Portuguese and with neighboring Southeast Asian states, were not only struggles between competing worldviews but also contests for the control of trade. Similarly, the leaders of the Darul Islam rebellion of the 1950s, while sincere in their pursuit of Islamic ideals, were partly driven by a desire to maintain the considerable autonomy, in economic and other spheres, they had come to enjoy in the late 1940s. Moreover, their resentment toward the central government was deepened by a feeling that the substantial economic contributions they had made to the Republic of Indonesia during the National Revolution had not been properly appreciated or recognized. ${ }^{17}$

Economic issues were also important in stimulating the New Order conflict between Aceh and Jakarta starting in the mid-1970s. In part, this was because Aceh happened to be extremely rich in natural resources-including oil, natural gas, timber, and a variety of valuable minerals-which began to be exploited to an unprecedented degree during this period. Perhaps even more significant was the manner in which New Order authorities set about exploiting those resources and distributing the benefits. One distinctive feature of that approach-and one of the reasons that massive exploitation of resources took place at all-was the very close relationship that the regime developed with foreign capital. That relationship was based partly on an ideological predisposition within the leadership group, but increasingly on the enormous material benefits that it brought both to the state and to individual officials, in the form of kick-backs, rents, fees, bribes, and so on. A second critical feature of the regime's approach was the highly centralized nature of its procedures for economic decision-making. ${ }^{18}$

The close nexus between state and capital, and the extreme centralization of economic decision-making, brought untold benefits to the New Order and to foreign capitalists operating in Aceh from the mid-1970s on. Simultaneously, however, it set in motion a variety of changes that generated popular support for Aceh Merdeka and contributed to the problem of unrest and violence.

\footnotetext{
17 Mr. S. M. Amin, "Sejenak Meninjau Aceh, Serambi Mekkah," pp. 70-74.

18 Kell offers the following summary of the problem of centralization: "Whatever plans the regional administration may have for the development of the Acehnese economy, the province lacks autonomy in economic matters by virtue of the highly centralized nature of state power under the New Order. Not only does the central government control the revenues that accrue from Aceh's export industries, but the concentration in Jakarta both of authority over industrial policy and of the bureaucratic agencies which grant licenses for new industrial projects also has strong 'Java-centric' effects. The pattern is accentuated by an additional 'web of informal connections' which ensures, for example, that military and government officials ... reap the greatest reward from the negotiation of local equity in foreign owned ventures." Kell, The Roots of Acehnese Rebellion, p. 27.
} 


\section{The LNG Boom}

From the mid-1970s through the 1980s, Aceh was catapulted from its status as an economic backwater into the fastest growing provincial economy in the country. ${ }^{19}$ The transformation has been dubbed the "LNG boom," because it was driven by the discovery and exploitation of huge desposits of liquid natural gas (LNG) and oil in the vicinity of Lhokseumawe and Lhoksukon, on Aceh's northeast coast. By the mid-1980s, as a result of the boom, Aceh's per capita GDP was equal to 282 percent of the national average, making it the third highest in the country. ${ }^{20}$ Over the same period Aceh became one of Indonesia's most important export earners and sources of central state revenue. Through the 1980 s it contributed between $\$ 2$ and $\$ 3$ billion annually to Indonesian exports, making it the third largest source of exports after Riau and East Kalimantan. ${ }^{21}$ Meanwhile taxes and royalties from the oil and gas fields contributed billions of dollars annually to central government revenues. ${ }^{22}$

The LNG boom appears to have provided fertile soil in which the rebel movement emerged in 1976 and again in 1989.23 In part, this was because the benefits of the boom were not equally shared. As the central government and foreign companies reaped enormous revenues, the promised "trickle down" effects of the massive investment proved to be limited. After the initial construction phase in the early 1970s, for example, employment opportunities for local people declined dramatically, and the majority of well-paid jobs were filled by Indonesians from different regions or by foreigners. ${ }^{24}$ The problem of unemployment was especially acute in the town of Lhokseumawe, in the immediate vicinity of the major production facilities. ${ }^{25}$ And

19 Aceh had by far the highest annual growth rate in the country between 1976 and 1982. Dayan Dawood and Sjafrizal, "Aceh: The LNG Boom and Enclave Development," in Unity and Diversity: Regional Economic Development in Indonesia Since 1970, ed. Hal Hill (Singapore: Oxford University Press, 1989), p. 111.

Although it has slowed considerably since then, Aceh's growth rate has remained strong. In the period 1994-1997, for example, growth averaged 7.86 percent per annum. Bappeda Propinsi Daerah Istimewa Aceh, "Pembangunan Ekonomi di Daerah Istimewa Aceh," Paper prepared for symposium, Telaah Pembangunan Daerah Istimewa Aceh Memasuki Era Reformasi, Jakarta, August 22, 1998.

${ }^{20}$ The figure for Aceh's per capita GDP in 1983 was Rp.1,220,000, up dramatically from Rp.28,000 in 1971. Only the provinces of Riau and East Kalimantan had higher per capita GDP in 1983. Hal Hill, ed., Unity and Diversity: Regional Economic Deoelopment in Indonesia Since 1970 (Singapore: Oxford University Press, 1989), pp. 6-7. For a synopsis of Aceh's contribution to the national economy, see Kell, The Roots of Acehnese Rebellion, pp. 14-16.

21 Dawood and Sjafrizal note that, by 1984, Aceh's "... net exports accounted for about two thirds of the provincial GDP. Thus well over half of Aceh's production accrues, through the central government, to the rest of Indonesia." Dawood and Sjafrizal, "Aceh," p. 115. The situation has not changed significantly since then. In the mid-1990s Aceh was contributing roughly 17 percent of Indonesia's total foreign exchange earnings. See Zulkifli Husin, "Strategi Pembangunan Ekonomi Aceh Dalam Order Reformasi," Paper prepared for symposium, Telaah Pembangunan Daerah Istimewa Aceh Memasuki Era Reformasi, Jakarta, August 22, 1998, p.1.

22 Dawood and Sjafrizal write that: "Virtually the entire oil and gas revenue from Aceh accrues to the central government, either through the production sharing agreement between MOI and Pertamina, or directly through Pertamina itself." Dawood and Sjafrizal, "Aceh," p. 115.

23 Detailed discussion of the socio-economic impact of the economic boom in Aceh can be found in Kell, The Roots of Acehnese Rebellion, pp. 16-21, and 52-60.

${ }^{24}$ Ibid., Pp. 19-20.

25 Dawood and Sjafrizal, “Aceh," p. 117. 
while the absolute level of poverty in the province was said to be relatively low by national standards, in the mid-1980s it was still the case that fewer than 10 percent of villages in energy-rich Aceh had a steady supply of electricity. ${ }^{26}$

Unsurprisingly, the boom also brought a number of undesirable side-effects, including the expropriation of land from small farmers without adequate compensation, ${ }^{27}$ the failure to provide adequate social amenities and infrastructure for displaced communities and migrant workers, ${ }^{28}$ and serious environmental degradation in the vicinity of the plants. ${ }^{29}$ These problems were compounded by the sometimes extreme insensitivity of Indonesian government and military authorities toward local people, who were commonly described as "fanatics," whose culture and worldview were in need of modernization and improvement. ${ }^{30}$ In return, some Acehnese blamed "outsiders" for encouraging practices they found offensive to Islam and to local custom, such as gambling, drinking, and prostitution.

Worse still, the substantial revenues generated by taxes and royalties were channeled directly to the central government, and there was a perception that very little was recycled back to the province in the form of government investment or subsidies. Of course Aceh was not alone in this regard, and it was hardly the worst off among Indonesia's provinces. ${ }^{31}$ Nevertheless, the fact that Aceh was contributing so much to national revenues and exports helped to create a feeling of resentment that it was not getting a great deal more in return. ${ }^{32}$ The skimming of tax and other revenues by the center was especially irritating to Acehnese intellectuals and local government technocrats, who felt that far more of the locally generated revenues ought to have been spent locally. ${ }^{33}$

26 Ibid, p. 122. Nor has the situation improved dramatically since then. In 1997, before the economic crisis, some 51 percent of Aceh's villages were categorized as poor. See Pengurus Pusat Taman Iskandar Muda, "Kerangka Acuan Diskusi Terbatas Telaah Pembangunan Daerah Istimewa Aceh Memasuki Era Reformasi," Jakarta, August 22, 1998, p.1.

27 The full extent of such expropriations began to be revealed in late 1998, as those who had lost their land began to seek compensation. In December 1998 four villagers from Desa Ampeh, Aceh Utara, brought a legal suit against Mobile Oil for land they said had been expropriated without compensation in 1977. Waspada, December 18, 1998.

28 Dawood and Sjafrizal, "Aceh," p. 117.

29 See George Aditjondro, "After Ogoniland, will it be the turn of Aceh? Notes on environmental degradation and human rights violations in Aceh," [Manuscript, n.d.].

30 A paper prepared for the Badan Perencanaan Pembangunan Aceh (Aceh Development Planning Board) in 1971 declares: "Aceh is well known for its religious fanaticism and its cultural fanaticism . ... That condition will make it difficult for the society to progress; it will remain static, not dynamic." A. Madjid Ibrahim, "Strategi Pembangunan Daerah Aceh," in Bunga Rampai tentang Aceh, ed. Ismail Suny (Jakarta: Bhratara Karya Aksara, 1980), pp. 469-470.

31 Dawood and Sjafrizal write that "government expenditure and revenue in Aceh is a surprisingly low share of GDP for a small province." They caution, however, that the figures may be misleading. Dawood and Sjafrizal, "Aceh," p. 113.

32 Kell, The Roots of Acehnese Rebellion, pp. 54-55.

33 A number of authors have described the rise of a class of technocrats in New Order Aceh, but the political role of this group remains ambiguous. While on the one hand they have been described as tools of the New Order state, it is clear that they gave expression to many of the grievances over Aceh's unfair treatment by Jakarta. Kell writes, for example, that ". . . for the technocrats, Aceh's difficulty was that it 
Members of Aceh's small but growing business class were unhappy for slightly different reasons. Though some benefited from the injection of private foreign investment in the region, many felt aggrieved because outsiders, particularly those with good political connections in Jakarta, or with the military in Aceh, appeared to be winning more than their share of lucrative contracts. Among the disgruntled businessmen was none other than Aceh Merdeka leader, Hasan di Tiro, whose bid for building a pipeline for Mobile Oil was reportedly beaten out by a US firm in $1974 .^{34}$ Perhaps not surprisingly, therefore, members of all these groups-intellectuals, technocrats, and businessmen-were among the strongest supporters of Aceh Merdeka.

Aceh's newfound economic importance guaranteed that central government and military authorities would respond swiftly, and with considerable force, to any perceived threats to security in the region, especially those in the immediate vicinity of the production facilities. By all accounts, the actual military threat from Aceh Merdeka was minuscule in 1977 and only slightly greater in 1989. Though faced with only a few dozen armed insurgents, on both occasions the government deployed many thousands of troops. ${ }^{35}$ The preoccupation with guarding the LNG facilities could also be seen in the fact that the Military Operations Command for Aceh was located in the provincial town of Lhokseumawe, right next door to the major LNG production facilities. ${ }^{36}$ The regime's approach was neatly encapsulated by Colonel Sofyan Effendi, the Commander of Korem 011 in Lhokseumawe, in mid-1990. He said the military would maintain "very strict" security in the area because it "contained five major industries important to the nation's economic growth." The authorities would be taking no risks, Effendi said, because "the slightest disturbance would have a national impact." 37 The irony was, of course, that in their bid to make Aceh secure and peaceful for economic development, New Order authorities achieved precisely the opposite result.

Aceh's status as a Military Operations Area also created unrivaled opportunities for the emergence of a semi-official mafia with close links to the military, and to Kopassus in particular. Members of units stationed in Aceh were apparently able to enrich themselves serving as enforcers, debt-collectors, security guards, and extortionists. ${ }^{38}$ Stories of such operations began to abound in Aceh as Kopassus became firmly entrenched in the mid-1990s. In 1997, a local human rights organization reported the case of a man named Abdul Hamid bin Itam who had been detained by three Kopassus soldiers late at night on September 14, 1996, in the town of Sigli. After being taken to the local Kopassus post, bin Itam had been badly beaten, and then shot in the head; his mutilated body was found a few days later about two hundred kilometers from Sigli. Although at first this appeared to be a standard summary

had been denied its fair share of the national economic cake and in the process had been relegated to the status of a neglected and disadvantaged outlying region." Ibid., p. 30.

34 Sumatra Human Rights Watch Network, "Tentang Aceh," [manuscript, n.d.].

35 On the military response in the late 1970s, see Nazaruddin Sjamsuddin, "Issues and politics of regionalism," p. 114. On the response after 1989, see below.

36 The Commander of the Military Operations Command (Pangkolakops) for Aceh was simultaneously the Commander of Korem 011/Lilawangsa, based in Lhokseumawe, Aceh Utara.

37 Jakarta Post, May 14, 1990.

38 See Far Eastern Economic Review, November 19, 1998, pp. 25, 18 ; and Gatra, August 15, 1998, p. 38. 
138 Geoffrey Robinson

execution of an Aceh Merdeka suspect, it was later reported that the dead man had been detained in connection with a private dispute he had had with a local government official in Pidie. The official had evidently hired the Kopassus soldiers to "resolve" the dispute. ${ }^{39}$

Although evidence for the existence of such a military mafia remains largely anecdotal, its existence would be in keeping with patterns in other parts of the country, and in particular in other areas of long-term military operations. It would also help to account for the extraordinary reluctance of the armed forces to leave Aceh, and to end the military operation there long after Aceh Merdeka appeared to have been crushed as a military force.

\section{The Logic of Rebellion}

The conjuncture of these trends-the growing importance of Aceh's economy for the central government, the failure of the LNG boom to provide the kinds of benefits anticipated by ordinary people, the problem of military heavy-handedness, and the emergence of a military-linked mafia-led inevitably to growing tensions between Acehnese on the one hand and central government and military officials on the other. Because these trends affected a fairly broad spectrum of Acehnese society, including farmers, fishermen, laborers, unemployed migrant workers-as well as the small Acehnese political, technocratic, and economic elite-they had the effect of increasing the credibility, and broadening the appeal, of the demands made by Aceh Merdeka's leaders.

The timing of Aceh Merdeka's rise, the targets of its attacks, and its geographical focus, lend additional support to the view that the movement was stimulated by the tensions generated by New Order economic policy. It was probably not by chance, for example, that Aceh Merdeka's declaration of rebellion in late 1976 and its first military action in 1977 coincided with the opening of PT Arun, Aceh's first major facility for the extraction and processing of LNG. ${ }^{40}$ Nor could it be mere coincidence that two of the plant's personnel, expatriate employees of Mobile Oil Indonesia (MOI), were among the first targets of rebel attacks in 1977.41 Evidently, the Aceh Merdeka leadership viewed the plant and its personnel as symbols of what was wrong in Aceh, and calculated that assaults on the new facilities would draw the maximum possible attention to their cause. Likewise, it was probably significant that the second Aceh Merdeka uprising in 1989 began with protests against the corruption, gambling, and prostitution that were said to have been encouraged by the flood of transmigrants and other "outsiders" whose numbers had increased during the boom. ${ }^{42}$ Finally, it was

\footnotetext{
39 For this and other cases, see Sjaifuddin Gani, "Kasus Aceh: Teror Kontra Teror Sebagai Kondisi Umum," [manuscript, n.d.], p. 9, and Sumatra Human Rights Watch Network, "Kondisi HAM di Aceh 1995-1997, [manuscript, n.d.], pp. 2-3.

40 The massive natural gas reserves were discovered in 1971, but production did not begin until 1977. PT Arun was established as a joint venture between the state oil company Pertamina, Mobile Oil Indonesia (MOI), and a consortium of Japanese companies. Dawood and Sjafrizal, "Aceh," p. 115.

41 Aditjondro, "After Ogoniland, will it be the turn of Aceh?," p. 2.

42 For details of these early protests, and attacks, see Amnesty International, Shock Therapy, p. 8.
} 
notable that the movement's base areas in 1976 and 1989-Pidie, Aceh Utara, and Aceh Timur-overlapped closely, though not completely, with the main areas of rapid industrial development.

This is not to say that Aceh Merdeka emerged directly in response to the LNG boom in the 1970s, but rather that the changes set in motion by the state-capital link, and the extreme centralization of economic decision-making, stimulated a consciousness of shared fate that reinforced existing ideas of Acehnese identity and increased the credibility of Aceh Merdeka in the area. The fact that the main LNG and oil facilities were located in the former base areas of the Darul Islam rebellion and the Aceh War, as well as on the home turf of Hasan di Tiro, gave a special resonance to the calls for rebellion and independence in these areas. The significance of economic developments in generating the conflict in Aceh is highlighted by the remarkable quietness of the province through most of the 1960s and early 1970s. The contrast can be explained, in part, by the fact that in those years Aceh was of no great interest economically, and so was largely left alone by the center. With the start of LNG production in the mid-1970s, however, Aceh became a magnet for the greedy and the powerful, and therefore a site of economic and political contention.

Yet, while the rapid economic transformations of the 1970s and 1980s undoubtedly contributed to the rise of Aceh Merdeka, and to the heightened central government concern over stability in the area, they do not appear to account for the extreme levels of violence that engulfed the area from mid-1990 to 1993. Nor do they explain the sudden resurgence of political violence in late 1998. Part of the explanation lies in the behavior of Aceh Merdeka itself, because its ideology of explicit separatism, its bellicose anti-Javanese rhetoric, its strategy of armed resistance, and its attacks on vital industries and transmigrants have seemed designed to provoke the most hostile possible reaction from the Indonesian armed forces. Yet, when the story is told from the perspective of Acehnese who experienced these events first-hand, it becomes clear that the degree and nature of the violence in Aceh after 1990 was even more closely related to the behavior of Indonesia's armed forces. That is to say, the actions of the Indonesian military in Aceh need to be examined not simply as a response to a mature rebellion, whose "roots" lay somewhere in the socio-economic or primordial past, but as an integral part of the development of that rebellion, and of the condition of recurrent violence and instability which grew from it.

\section{Military Doctrine and Practice}

The use of military force to deal with armed insurgents was not, of course, an innovation of the New Order. Dutch colonial forces behaved with conspicuous brutality in Aceh, and in some other parts of the archipelago, as the Dutch sought to extend their administrative authority to previously autonomous areas in the late nineteenth century. Under President Sukarno, combat troops had been deployed throughout the country, including in Aceh, to put down rebellions and insurrections. The soldiers of the Old Order were, on occasion, accused of serious abuses, including torture and rape. Christie writes, for example, that in Aceh in the 1950s "the response 
of the government troops to rebel actions tended to be clumsy and brutal ... [and] this had the inevitable effect of increasing sympathy and support for the rebels."43

What was new, and distinctive, about military doctrine and practice under the late New Order was: first, the institutionalization of terror as a method for dealing with perceived threats to national security; and second, the systematic and forced mobilization of civilians to serve as auxiliaries and spies in counter-insurgency operations. ${ }^{44}$ These features of New Order military doctrine and practice ensured that in Aceh a much broader spectrum of people came to experience the hard edge of the regime, to feel deep bitterness towards it, and to sympathize more completely with the opposition. These methods also encouraged greater violence and disruption in local society, and inflicted wounds that would prove exceptionally difficult to heal.

\section{Terror}

Mid-1990 is a critical date in this story because it marks the abrupt end of the regime's limited efforts to resolve the conflict in Aceh through political accommodation and negotiation, and the beginning of a wholly military response. ${ }^{45}$ Once the new combat troops had been deployed, in mid-1990, and the counterinsurgency campaign known as Operasi Jaring Merah set in motion, the level and the nature of violence began to change almost immediately. Though there was little press coverage at the time, it later became clear that it was at this stage that the armed forces began to employ terror systematically. ${ }^{46}$ As Amnesty International wrote in 1993: "The political authority of the armed forces, considerable even under normal conditions, now became unchallengeable. In the name of national security, military and police authorities deployed in Aceh were thereafter free to use virtually any means deemed necessary to destroy the GPK."47

Among the first outside troops to arrive in Aceh was a Kostrad unit under the command of Colonel Prabowo Subianto. ${ }^{48}$ Within a few days of their arrival by

43 Christie, A Modern History of Southeast Asia, p. 154. One estimate from 1955 claims that 271 people were killed in the fighting between 1953 and 1954. Teungku Hadji Ali, cited in Kompas, August 11, 1998.

44 The origins and evolution of these features of New Order military doctrine and practice have been analyzed in some depth by Tanter, Van Langenberg, and others. See Richard Tanter, "The Totalitarian Ambition: Intelligence Organisations and the Indonesian State," in State and Civil Society in Indonesia, ed. Arief Budiman (Clayton, Victoria: Monash Papers on Southeast Asia, No. 22, 1990); and Michael van Langenberg "The New Order State: Language, Ideology, Hegemony," in State and Civil Society in Indonesia, ed. Arief Budiman.

45 The contrast with the increasingly accommodative approach adopted by Sukarno toward the 1950s Darul Islam rebellion is instructive. As Sjamsuddin writes: "In Aceh, the political concessions granted by the Old Order regime played a great part in ending the Darul Islam rebellion in the early 1960s." Sjamsuddin, "Issues and politics of regionalism," p. 124.

46 Detailed descriptions of the use of terror can be found in Amnesty International, Shock Therapy; Kompas, August 22, 1998; Gatra, August 8, 1998; Ummat, August, 1998; Xpos, August 1-7, 1998; DeTak, August 11-17 and August 18-24, 1998; and Seuruenee: Bulletin Forum LSM Aceh, July 1998.

47 Amnesty International, Shock Therapy, p. 11.

48 The unit was probably the $17^{\text {th }}$ Airborne Infantry Brigade, of which Prabowo became Chief of Staff in 1989, immediately after a successful tour of duty in East Timor as deputy Commander of Kostrad Battalion 328. Forum Keadilan, August 24, 1998. 
parachute in Aceh Utara, this unit began to burn down the houses of families suspected of supporting Aceh Merdeka. ${ }^{49}$ That was only the start. In subsequent weeks, this and other military units began a systematic campaign to terrorize civilian populations in areas of presumed rebel strength. Their methods included armed nighttime raids, house-to-house searches, arbitrary arrest, routine torture of detainees, the rape of women believed to be associated with the movement, and public execution. 50

Among the most chilling examples of state-sanctioned terror in Aceh were targeted killings and public executions. For a period of about two years after the start of combat operations, the corpses of Acehnese victims, generally young men, were found strewn in public places-beside main roads, near village security posts, in public markets, in fields and plantations, next to a stream or a river-apparently as a warning to others not to join or support the rebels. Amnesty International reported the following patterns:

Their thumbs, and sometimes their feet, had been tied together with a particular type of knot. Most had been shot at close range, though the bullets were seldom found in their bodies. Most also showed signs of having been beaten with a blunt instrument or tortured, and their faces were therefore often unrecognizable. For the most part, the bodies were not recovered by relatives or friends, both out of fear of retribution by the military and because the victims were usually dumped at some distance from their home villages. ${ }^{51}$

In technique and in evident purpose, these killings closely resembled the government-sponsored summary executions of alleged petty-criminals in the mid1980s. Known by the acronym Petrus, the earlier "mysterious killings" had left some five thousand people dead in Java and other parts of the country. Though government and military authorities had initially denied any involvement in the Petrus killings, it eventually emerged that they had been initiated by the regime itself and carried out by a specially trained sub-unit of Kopassus. ${ }^{52}$ It was also revealed that the use of terror had had a deliberate strategic intent. In his memoirs, published in 1989, Suharto provided the following rationale for the killings.

The peace was disturbed. It was as if there was no longer peace in this country. It was as though all there was was fear ... We had to apply some treatment, to take some stern action. What kind of action? It had to be with violence. But this violence did not mean just shooting people, pow! pow! just like that. No! But those who tried to resist, like it or not, had to be shot ... . Some of the corpses were left [in public places] just like that. This was for the purpose of shock therapy ... This was done so that the general public would understand that there was still someone capable of taking action to tackle the problem of criminality. ${ }^{53}$

\footnotetext{
49 Confidential personal communication from human rights lawyer, Banda Aceh, August 1998.

50 For examples and eyewitness testimonies, see Amnesty International, Shock Therapy.

51 Ibid., p. 18.

52 On the Petrus killings, Bourchier concludes that "The timing, the methods used and the geographical spread of the killings ... indicate a well planned, centrally coordinated military operation." Bourchier, "Law, Crime and State Authority in Indonesia," in State and Civil Society in Indonesia, pp. 186-187.

53 Suharto: Pikiran, Ucapan dan Tindakan Saya (Jakarta: PT Citra Lamtoro Gung Persada, 1989), p. 364.
} 
Like the Petrus killings, the "mysterious killings" in Aceh were clearly part of a central government policy that involved the deliberate use of "shock therapy" to achieve a strategic security and political objective. ${ }^{54}$ There can be no other explanation for the many documented instances in which military authorities severed the heads of alleged rebels and placed them on stakes in front of their command posts, or in public markets. Nor is there any other way to explain why military officers forced passersby to witness the roadside executions of rebel suspects. ${ }^{55}$ Besides the testimony of witnesses, the evidence to support this claim comes from the statements of the military authorities involved. Commenting on the public display of corpses, for example, one military officer in Aceh admitted: "Okay, that does happen. But the rebels use terrorist strategies so we are forced to use anti-terrorist strategies." 56 Asked whether the mysterious killings were intended as "shock therapy" the Regional Military Commander, Major General R. Pramono, said: "As a strategy, that's true. But our goal is not bad. Our goal must be correct... We only kill them if they are members [of Aceh Merdeka]."57

Many victims of summary execution were simply shot and thrown into mass graves, at least one of which reportedly contained as many as two hundred bodies. Commenting on reports of such a mass grave in late 1990, Major General R. Pramono told a journalist: "The grave certainly exists but I don't think it could have been two hundred bodies. It's hard to tell with arms and heads all mixed up."58 But if the method of disposal was different, the intent of the mass killings was the same: to sow terror, to create an atmosphere of fear, and to ensure that witnesses to such crimes remained silent. The strategy worked, at least in the short term. As a man who lived near the site of a mass grave commented in 1998: "At that time, trucks carrying bodies to be buried on the peninsula or just dumped on the streets came and went at night, while people were too scared to ask what happened." 59 In the long term, however, the military's use of terror stimulated a profound anger among a broad cross-section of Aceh's population. That anger was fueled by the Habibie government's failure to take

\footnotetext{
54 Amnesty International concluded that: "The timing of the worst killings in Aceh, the methods and techniques employed, and the comments made by military officers in the region, suggest strongly that extrajudicial execution was part of a deliberate and coordinated counter-insurgency strategy. Moreover, the uniformity of the pattern of human rights violations reported in Aceh and those documented in other parts of Indonesia and East Timor, indicates that, where it faces serious opposition to its authority, political killing may be a central aspect of Indonesian Government policy." Amnesty International, Shock Therapy, p. 18.

55 For details of such cases, see Amnesty International, Shock Therapy, pp. 22-27; and Sjaifuddin Gani, "Kasus Aceh: Teror Kontra Teror Sebagai Kondisi Umum," [manuscript, n.d.], pp. 5-8.

56 Reuter, November 25, 1990.

57 Ibid.

58 Ibid. In late August 1998, Indonesia's National Human Rights Commission excavated several of the suspected mass grave sites. Commenting on their findings a member of the commission said: "The discovery of the skeletal remains has convinced us beyond doubt that the reports of widespread military atrocities over the past nine years in Aceh are an undisputed fact." Jakarta Post, August 28, 1998. For further details of those investigations and of the mass graves, see the Commission's report, "Laporan Komnas HAM: Dari Kuburan Massal Hingga Cuwak," August 24, 1998. Also see Kompas, August 22, 1998; Jakarta Post August 22, 1998; and Waspada, August 14, 1998.

59 Jakarta Post, August 22, 1998.
} 
action against the military perpetrators. Under the circumstances, the assaults on military and police personnel in late 1998 were hardly a surprise.

\section{Civil-military cooperation}

Equally important in generating political violence in Aceh was the New Order strategy of "civil-military cooperation"-a euphemism for the policy of compelling civilians to participate in intelligence and security operations against real or alleged government opponents. ${ }^{60}$ Like the use of targeted killings, corpse display, and rape, this strategy was not unique to Aceh, having been developed and refined, for example, in counter-insurgency operations in Irian Jaya and East Timor.

Among the most notorious examples of the strategy were the "fence of legs" operations-used both in East Timor and in Aceh-in which "ordinary villagers were compelled to sweep through an area ahead of armed troops, in order both to flush out rebels and to inhibit them from returning fire."61 The idea behind the strategy was succinctly stated by Colonel Syarwan Hamid in 1991, when he was the Commander of Korem 011, and simultaneously of the Military Operations Command for Aceh: "The youths are the front line. They know best who the GPK are. We then settle the matter." 62 Priests who witnessed such an operation in East Timor described it as the ". . . mass mobilization of citizens to make war on each other." 63

More widely used in Aceh, and with similar consequences for local communities, were military-led campaigns encouraging all civilians to hunt and kill any suspected member of an alleged enemy group. This was an essential element in the dynamic of violence in Aceh. In November 1990, for example, Major General R. Pramono, said:

I have told the community, if you find a terrorist, kill him. There's no need to investigate him. Don't let people be the victims. If they don't do as you order them, shoot them on the spot, or butcher them. I tell members of the community to carry sharp weapons, a machete or whatever. If you meet a terrorist, kill him. ${ }^{64}$

Apparently seeking to reassure a western journalist that such methods were humane and appropriate, he commented: "We have written laws and unwritten laws ... The people know the unwritten laws so they won't kill anyone who's not in the wrong. Well, one or two maybe, but that's the risk." 65

Also commonly employed in counter-insurgency operations in Aceh were local vigilante units and night patrols made up of civilians but established under military

\footnotetext{
60 The strategy was officially justified by the military doctrine known as "People's total defence and security system" (sishankamrata).

61 Amnesty International, Shock Therapy, p. 12.

62 Kompas, July 11, 1991.

${ }^{63}$ Cited in John Taylor, Indonesia's Forgotten War: The Hidden History of East Timor (London: Zed Books, 1991), p. 117. The "fence of legs" strategy was used in East Timor in Operasi Keamanan in 1981 and Operasi Kikis in 1986-1987. For a detailed description of these operations, see Taylor, pp. 117-118 and 161.

64 From an interview with Major General R. Pramono, Tempo, November 17, 1990; translation as cited in JPRS-SEA-90-034, December 16, 1990.

65 Reuter, November 25, 1990.
} 
order and supervision. They included groups such as the Unit Ksatria Penegak Pancasila (Noble Warriors for Upholding Pancasila), Bela Negara (Defend the Nation), Pemuda Keamanan Desa (Village Security Youth), and Laskar Rakyat (People's Militia). In the first few years of the operation alone, military authorities mobilized tens of thousands of men into such units. ${ }^{66}$ Recruits received basic military training and, after being armed with knives, spears, and machetes, were told to "hunt" Aceh Merdeka supporters. As they had done during the anti-communist campaign in 19651966, and during counter-insurgency operations in East Timor, military authorities also organized mass rallies in Aceh at which civilians were exhorted to "crush the GPK," and to swear an oath that they would "crush the terrorists until there is nothing left of them." 67 The failure to participate in such campaigns-or to demonstrate a sufficient commitment to crushing the enemy by identifying, capturing, or killing alleged rebels - often resulted in punishment, and sometimes public torture and execution. 68

The strategy of "civil-military cooperation" also entailed the recruitment of local people to serve as spies and informers for the military. One consequence of this arrangement was the reinforcement of an atmosphere of pervasive fear and silence. One simply did not know who might be listening. As an Acehnese human rights activist said in August 1998: "We have lived for years with fear. During the New Order, we kept our mouths shut, never daring to speak out . . . because in every café and street corner there were intelligence agents listening." 69

The strategy bred terrible tensions and conflicts among Acehnese. Perhaps with honorable intentions, many Acehnese of some social standing-including members of the Majelis Ulama Indonesia (MUI, Indonesian Council of Ulamas)-joined the army's counter-insurgency campaign. ${ }^{70}$ Others, possibly fearing the repercussions of noncooperation, became enthusiastic spies and informants for the military. In doing so, they helped to send hundreds, perhaps thousands of fellow Acehnese to their graves. The wounds caused by such actions do not heal easily. Predictably perhaps, in the months after the withdrawal of combat troops in August 1998, Acehnese collaborators, known locally as cuak, were subjected to violent reprisals. At least two were beaten to death by angry crowds, while others were forced to seek protection with local authorities. ${ }^{71}$ Like the attacks on military and police personnel, the violence against collaborators seemed likely to continue for some time, another long-term legacy of New Order military strategy.

\footnotetext{
66 In mid-1991 the Governor of Aceh, Ibrahim Hasan, estimated that some sixty thousand people had been mobilized. Kell, The Roots of Acehnese Rebellion, p. 75.

67 Amnesty International, Shock Therapy, pp. 13-14.

68 Confidential interviews with Acehnese refugees in Malaysia, October 1991; and Amnesty International, Shock Therapy, p. 13.

${ }^{69}$ Kompas, August 11, 1998. A key figure in the development of this network was the chief of the intelligence task force in Aceh in the early 1990s, Colonel Zacky Anwar Makarim. In 1997 Makarim, by then a Major General, was appointed head of BIA, the powerful armed forces intelligence agency, a position he retained in late 1998. Far Eastern Economic Review November 19, 1998, p. 28; Gatra, August 15, 1998.

${ }^{70}$ For more details of the role of the MUI in the counter-insurgency campaign, see Kell, The Roots of Acehnese Rebellion, pp. 77-78.

71 Far Eastern Economic Review, November 19, 1998.
} 
Yet while the methods employed by the military generally helped to perpetuate a cycle of violence they also served to stimulate a significant shift in Acehnese public discourse. Whereas in 1976-1979, and still in 1989-1990, Aceh Merdeka sympathizers rallied principally around issues of economic injustice and political self-determination, after 1991 the main focus of concern shifted to ABRI's behavior, and to its systematic violation of human rights. That change may have represented a tactical decision by the Aceh Merdeka leadership, in an effort to garner greater domestic and international support for the cause. Its effectiveness as a tactic, however, lay in the grim reality that ABRI (Angkatan Bersenjata Republik Indonesia, The Armed Forces of the Republic of Indonesia) was in fact committing the most outrageous crimes against ordinary people.

The shift in focus became even clearer after the collapse of the New Order in May 1998. Driven largely by the energetic work of a handful of non-governmental organizations (NGOs), and by some unusually bold domestic media coverage, a variety of official bodies and high-ranking authorities undertook fact-finding missions to the region in mid-1998. Among the first was armed forces commander General Wiranto who visited the province in early August. ${ }^{72}$ After a series of meetings with military officials, NGOs, and community groups, Wiranto stunned the country with a public apology for human rights violations committed by $A B R I$ over the previous nine years. He also announced that Aceh's status as a Military Operations Area would be lifted by the end of the month. ${ }^{73}$ Wiranto's announcements appeared to be part of an effort to discredit his arch-rival, Prabowo Subianto, and to distance ABRI as an institution from any wrong-doing. Nevertheless, his remarks opened the door to further investigations of military responsibility and to more discussion in the media.

Soon, high-ranking government authorities were rushing to express their concern and their outrage over past violations. Once this had begun, it was impossible to stop the criticism from spreading. Acehnese, and other Indonesians, began to call openly not for Aceh's independence, and certainly not for an Islamic state, but for thorough investigations into military abuses committed over the previous ten years, for the punishment of the soldiers and officers responsible, and for compensation of the victims. While this shift did not result in the immediate punishment of those responsible for the abuses, it did substantially alter the political balance on the issue. The armed forces were clearly on the defensive for the first time, and the prospects for a proper investigation, while not great, were arguably better than they ever had been.

\section{Context and Change}

These recent developments highlight the importance of political and historical context in shaping both government policy in Aceh, and the patterns of violence that stem from it. Three factors appear to have been especially important in shaping New Order strategy in Aceh after 1989: a national and international political context conducive to terrorist methods; tensions within the military itself that encouraged a full-scale intervention by the center; and backgrounds in counter-insurgency and

\footnotetext{
72 Wiranto's visit came shortly after a fact-finding team from the national parliament (DPR) announced that serious human rights violations had indeed occurred in Aceh. See reports in Waspada, July 29, 1998, and Jakarta Post, August 6, 1998.

73 See reports in Kompas, August 11 and 26, 1998; and Jakarta Post, August 7 and 8, 1998.
} 
intelligence shared by the key military figures responsible for the operation. This section examines each of these factors in turn, considering first how they influenced the course of events after 1989, and then how recent changes might influence the future likelihood of political violence in Aceh.

\section{Models and opportunities}

The authorities who plotted the New Order's response to the Aceh Merdeka rebellions were influenced by contemporaneous events, both within Indonesia and abroad, and by memories of recent successes and failures. The models of action available to them, that is, were framed and limited by the historical circumstances and the timing of the events in question.

We have noted, for example, how Aceh Merdeka's emulation of the resistance in East Timor in the late 1970 s must have caused considerable alarm among the authorities in Jakarta, moving them to respond more forcefully than they might otherwise have done. At the same time, the fact that the regime was then in the midst of a major military campaign in East Timor meant that it could not afford to launch a full-scale counter-insurgency operation in Aceh as well. Moreover many of the most brutal tactics and methods that would later be employed in Aceh had not yet been fully developed or perfected when Aceh Merdeka launched its first rebellion in the late 1970s. By the time of the second uprising in 1989, the regime's counter-insurgency repertoire had expanded considerably. Techniques like the "mysterious killings" and the "fence of legs" had by then been tried and proven in the field and were available for "export" to Aceh and other trouble spots. The availability of those techniques meant that a type of systematic terror was possible in the early 1990s that would have been difficult to envision in the late 1970 s.

The timing of the government response to the second Aceh Merdeka uprising was significant in other ways as well. It should be recalled that the crackdown in Aceh began more than a year before the November 1991 massacre at Santa Cruz, East Timor, and the unprecedented criticism at home and abroad that stemmed from it. That criticism would eventually send shock waves through the regime and the armed forces, but in the years and months before the Santa Cruz massacre the regime's leading figures displayed a remarkable confidence about the success of their terrorist methods. It may be recalled that 1989 was the year East Timor was "opened up" to tourists and journalists for the first time in fifteen years. It was also the year President Suharto published the autobiography in which he took credit for, and gloated over the success of, the Petrus killings of the mid-1980s.

This was a time, too, when international criticism of the New Order's human rights record had reached a low ebb. Stimulated by a desire to capitalize on the then burgeoning economies of the region, Western governments were reluctant to voice concern about, or to take concrete measures in opposition to, the violations committed by Indonesian government forces. In these years Western governments routinely argued that the human rights situation in East Timor was improving, and that it was pointless and irresponsible to question the territory's political status. There was even less concern about human rights violations occurring in Indonesia itself. When Indonesian troops killed scores of Muslim villagers in the province of Lampung in 
February 1989, for example, there was scarcely a murmur of protest from the international community.

In short, the counter-insurgency campaign in Aceh was set in motion at a time when the New Order leadership had reason to believe that the brutal methods it had used in East Timor, Irian Jaya, Java, Lampung and other "trouble spots" had worked. Under the circumstances, they undoubtedly felt confident that the same methods could be used to good effect, and without serious political cost, in Aceh as well. That confidence was bolstered by their judgement that the international community would exhibit little sympathy for the victims in Aceh, if they could be successfully portrayed as dangerous Muslim fanatics.

That assessment was not far wrong. Long after the Santa Cruz massacre had forced recognition of the seriousness of the problem in East Timor, and at least some sort of response from the New Order, the widespread violations of human rights in Aceh received scarcely a mention either abroad or within Indonesia. The silence within Indonesia was not surprising, because legitimate fears of military retribution inhibited both the gathering of accurate information and its public dissemination. The inaction of the international community, on the other hand, was inexcusable. Most western and Asian governments maintained a deliberate silence on the subject even though they had credible information about what was happening, both from their own embassy officials, and from human rights organizations such as Amnesty International and Human Rights Watch. Among Asian governments, Prime Minister Mahathir's Malaysia was conspicuous for its hypocrisy. While berating Western governments for their failure to come to the aid of Muslims in Bosnia, Malaysian authorities returned dozens of Acehnese asylum seekers to Indonesia against their will, in violation of the internationally recognized principle of non-refoulement. ${ }^{74}$ The decision to maintain that unseemly silence, to conduct business as usual with the New Order, and to cooperate actively in the persecution of Acehnese, unquestionably helped to ensure that military operations, and human rights abuses, would continue in Aceh for nearly a decade.

By contrast, changes in the wider political context after May 1998 provide some grounds for optimism about Aceh's future. Notwithstanding the extreme reluctance of the Habibie government to take action, in late 1998 the domestic political climate was arguably more conducive to the investigation of human rights violations, and the punishment of those responsible, than at any time in the preceding three decades. The same was true of the international political climate, which appeared not only to support a shift toward democratization in Indonesia but also the punishment under international law of those responsible for egregious violations of human rights. ${ }^{75}$ The continuing economic crisis, moreover, left the Habibie regime vulnerable to, and dependent on, the demands of foreign creditors, and there was no indication in late 1998 that the latter favored a return to the corrupt authoritarian system which many blamed for the crisis. In any case, the avalanche of evidence of past wrong-doing by the military had left international actors with little choice but to support the process of

\footnotetext{
74 On the Acehnese asylum-seekers in Malaysia, see Amnesty International, Shock Therapy, pp. 53-56.

75 Among the most notable developments in this regard in 1998 were the agreement to establish an international criminal court, and the initiation by a Spanish magistrate of legal proceedings against General Pinochet of Chile for crimes against humanity.
} 
148 Geoffrey Robinson

reform and democratization. Indeed, the United States and other governments appeared to have given notice that any overt move toward the reassertion of military control of political life would not be welcome.

\section{Intra-military tensions}

The logic of the national and international context notwithstanding, it would be a mistake to imagine that the decision to launch a counter-insurgency campaign in Aceh in mid-1990 was reached through consensus among the military and political leadership. ${ }^{76}$ In fact, there is reason to believe that both the military campaign in Aceh, and the sudden growth of Aceh Merdeka in 1989, were stimulated by a conflict between the central military command and regional military and police authorities.

Looking first at the government side, we find several pieces of evidence that the military campaign coincided with an effort to restore central authority over the regional command structure. First, as noted earlier, the operation launched in mid1990 involved the deployment, on the direct orders of President Suharto, of some six thousand centrally commanded troops from outside the military operations area. This move suggested that the central command could not, or preferred not to, entrust the task of dealing with the rebels to the territorial command, despite its more than ample troop strength. 77

Second, the full-scale counter-insurgency campaign began within a few days of the replacement of the old Regional Military Commander, Major General Joko Pramono. When isolated rebel attacks and bombings began in early 1989, Joko Pramono had responded in a relatively low-keyed fashion. Rather than initiating armed intervention, he had first sought the assistance of Muslim community leaders to nip the incipient movement in the bud. ${ }^{78}$ By mid-1990, however, Joko Pramono had been replaced by $R$. Pramono, and the concerted campaign of political violence began in earnest.

Third, this centrally directed military operation began shortly after the replacement of the old commanders of Korem 011 and 012, both located in Aceh, by new men with close links to the center. After their removal, the military careers of the old Korem commanders essentially ground to a halt. The dismissed Commander of Korem 011, Colonel H.M. Ali Hanafiah, for example, became the Bupati of Labuhan Batu, North Sumatra, while the old Commander of Korem 012, Colonel Soehardjono, simply disappeared from the screen.

\footnotetext{
76 We know that conflicts among the Indonesian military elite have historically been important in stimulating serious political violence. In an analysis of the Indonesian military elite published in early 1992, for example, the Editors of Indonesia argued that the Santa Cruz massacre in East Timor may have been triggered by a festering conflict between elements of a local military-civilian "mafia" and representatives of the central military command installed to bring it under control. The Editors, "Current Data on the Indonesian Military Elite: July 1, 1989-January 1, 1992," Indonesia 53 (April 1992).

${ }^{77}$ Recent comments by Aceh's then Governor, Ibrahim Hasan lend support to this interpretation. In an interview in August 1998, Hasan explained that his decision to ask Jakarta to deploy extra troops was taken after Regional Military Commander Joko Pramono and the two Korem commanders in Aceh told him, somewhat implausibly, that they did not have sufficient troops to deal with the rebels. Republika, August 12, 1998.

${ }^{78}$ Kell, The Roots of Acehnese Rebellion.
} 
These changes came close on the heels of other moves by the center aimed at cleaning up the regional military apparatus. In early 1989 at least forty-seven Acehbased military officers were dismissed on disciplinary grounds. The dismissals took place in the context of a centrally coordinated anti-narcotics campaign, called Operasi Nila, which had resulted in the capture of thousands of tons of ganja and the exposure of key figures in the syndicate, including unnamed military and police officials. The timing of the disciplinary measures against the Aceh-based officers strongly suggested that those dismissed had been involved in the drug syndicate. This fact might account for the government's somewhat curious initial insistence that the trouble in Aceh in these years was the work of criminal rather than political elements, and that central military operations there were part of an anti-crime campaign. ${ }^{79}$

The central government crackdown on the drug racket in Aceh in 1989 may also help to explain the sudden increase in the armed strength of Aceh Merdeka and its renewed capacity and propensity for violence at this time. According to political observers in Aceh, in 1989 dozens of disgruntled ex-military and police-some of whom had been dismissed and others who had deserted-joined forces with Aceh Merdeka and began to launch coordinated assaults on military personnel and installations. ${ }^{80}$ The link between ABRI and Aceh Merdeka is confirmed by the fact that, of the fifty or so alleged Aceh Merdeka members or supporters tried in Indonesian courts by the end of 1992, no fewer than ten were ex-ABRI.81 It is perhaps noteworthy in this regard that marginalized military and police officers also formed an important fighting core of the Darul Islam rebellion in the 1950s, and of the OPM in Irian Jaya in the $1960 \mathrm{~s} .{ }^{82}$ Without the experience of such men on the side of the rebels, it may be argued, the Darul Islam, the OPM, and Aceh Merdeka rebellions might not have amounted to very much militarily.

\footnotetext{
${ }^{79}$ Speaking before the United Nations Commission on Human Rights in August 1991, the government said, for example: "What occurred in Aceh was that armed criminals spread terror and intimidation which caused disturbances and social unrest ... These occurred after the local authorities took stringent measures to eradicate the cannabis cultivation. Against these [sic] background the Indonesian authorities was [sic] forced to take action to restore peace and public order." Republic of Indonesia Right of Reply under Item 10, United Nations Commission on Human Rights, February 1991.

80 Reuter, July 22, 1990.

81 Amnesty International, Shock Therapy. One of the ex-ABRI men who bolstered Aceh Merdeka as a fighting force was the field commander, Robert Suryadarma, a former Army sergeant from Battalion 111 based in Aceh Timur who had reportedly been dismissed for his involvement in the drug trade. Acehnese refugees in Malaysia have reported interesting details about Robert, who went into hiding in Kuala Lumpur shortly after the government launched its full-scale military campaign in mid-1990. They have claimed, for example, that he was a follower of a certain Rizal Gading, a rival of Hasan di Tiro within Aceh Merdeka. Rizal Gading, in turn, is alleged to have had close ties to the former Indonesian intelligence boss, General Benjamin Murdani. Given the serious tensions between Murdani and the Palace that developed in the late 1980 s, it is not beyond the realm of possibility that Murdani lent his support to certain disgruntled elements in the military at this time. Nor is it entirely implausible that the center's moves to clean up the regional command in 1989 were aimed, in part, at weakening the grip of men with links to Murdani.

82 Referring to the Darul Islam rebels, the former Governor of North Sumatra, Mr. Amin, writes: "It was very well understood at the time that the rebellion would mean serious bloodshed, considering that those leading the resistance were men with military experience dating from the time of the struggle for independence." Amin, "Sejenak Meninjau Aceh, Serambi Mekkah," pp. 86-87.
} 
If the military action initiated in mid 1990 can be understood, in part, as. a campaign by the center and its allies in Aceh to oust a mafia with links to the military, developments after about 1993 may plausibly be seen as an effort by the center-and by Kopassus in particular-to maintain the central military control that had by then been established. This is certainly the view of many informed observers in Aceh, ${ }^{83}$ who have noted that, since 1993, all demands for the ending of military operations have been thwarted by acts of violence, some of them apparently instigated by the military itself.

Such acts have continued in recent times. Shortly after General Wiranto announced that Aceh's status as a Military Operations Area would be lifted in August 1998, a number of highly provocative incidents occurred in rapid succession, including an Aceh Merdeka flag-raising at a school just days after the announcement, and a wild stone-throwing attack (in which nobody was injured) on a unit of departing Kopassus troops. The latter incident was later reported to have been staged by a Kopassustrained vigilante youth organization, Pemuda Keamanan Desa, and there was a general perception that at least some of the other incidents, too, had been orchestrated to justify a reversal of the announced plan to end the military operation. Similar allegations were made in connection with the violence that erupted in late 1998, though it was too early to say whether these allegations were true. Yet, whatever its root causes, the recent violence did serve to justify the redeployment of combat troops in the province, leading many Acehnese to the pessimistic conclusion that a second counter-insurgency campaign was set to begin.

On the other hand certain developments after the demise of President Suharto in May 1998 made possible a cautious optimism about Aceh's future. While there was every likelihood that some officers would continue to seek a return to Aceh's status as a Military Operations Area, the dramatic decline nationwide in respect for and trust of the military, and the depth of public outrage over past human rights abuses, seemed likely to encourage the central command to resist that temptation. While such an act of restraint could not be expected to resolve immediately all outstanding problems, it would help to limit the chances for a dramatic re-escalation of violence.

\section{Profiles in terror}

While the decision to launch a counter-insurgency campaign in Aceh in mid-1990 may be attributable to military doctrine, and to tensions within the Indonesian military as an institution, the actual character of the operation must be understood in part as the responsibility of specific individuals, and more precisely the key military figures posted there at the time. A preliminary analysis of the training and experience of those men provides insight into the reasons for the peculiar savagery of the operations in the period 1989 to 1993. Simply stated, the officers responsible for operations in Aceh during these years were overwhelmingly men who had been trained in, or had firsthand experience with, the use of such tactics.

${ }^{83}$ The information in this paragraph is based on a confidential personal communication from an Acehnese human rights lawyer, Banda Aceh, August 28, 1998. 
Mention has already been made of Colonel Prabowo Subianto, Suharto's notorious son-in-law and protégé, whose arrival in Aceh in mid-1990 as a Kostrad unit commander coincided with the onset of the worst violence. Though, as we have seen, he was responsible for ordering acts of brutality in Aceh, Prabowo's significance in the story extends beyond his personal actions. His dramatic rise through the military hierarchy starting in the late 1980s arguably signaled President Suharto's endorsement of and enthusiasm for officers who had demonstrated their personal loyalty and who had a background in counter-insurgency and intelligence. Accordingly, when in 19891990 the Palace decided that there was a job to be done in Aceh, it appears to have turned to men of this ilk.

Virtually all of the commanders of Kodam 1, the Regional Military Command within which Aceh lay, had experience in one of the elite combat or counterinsurgency units-RPKAD, Kopassus, and Kostrad-or a background in military intelligence, or both. Most also had close links with the Palace. A similar tendency is evident for Chiefs of Staff of Kodam 1, and for the Commanders of the two Korem in the immediate area of military operations. 84

Of the two Korem in question, Korem 011/Lilawangsa, with its headquarters in Lhokseumawe, was arguably the most important because the Commander there doubled as Commander of the Military Operations Command, and therefore had direct responsibility for all combat and intelligence operations in Aceh. In the critical period from August 1989 to January 1991, the Commander of Korem 011 was Colonel Sofyan Effendi, who had previously served with the RPKAD and as Deputy Commander of Kopassus. After Effendi, most Korem 011 Commanders were also men with experience in intelligence or counter-insurgency. Colonel Sridono, who held the position from late 1992 to early 1994 had previously served as Assistant for Intelligence of Kodam 1, while his successor, Colonel Djoko Subroto, had served in Manatuto, East Timor, from 1987 to 1988, and from 1993 to 1994, as the commander of the Core Infantry Regiment of Kodam 1.85 Effendi's immediate successor in the post of Commander of Korem 011, Colonel Syarwan Hamid, who held the job from January 1991 to December 1992, was somewhat atypical in the sense that his experience was mainly in social-political affairs rather than counter-insurgency or intelligence. Nevertheless, his career trajectory both before and after his time in Aceh suggests that he had the trust of both the central military command and the Palace. ${ }^{86}$

84 The information in the following paragraphs is drawn from various editions of "Current Data on the Indonesian Military Elite," compiled by the editors of Indonesia. A listing of the key military figures posted in Aceh is provided in Appendix 1.

85 The same pattern was evident for commanders of Korem 012/Teuku Umar, with its headquarters in Banda Aceh. From April 1989 to August 1992, the Commander of Korem 012 was Colonel Muhammad Chan whose previous position had been as Assistant for Intelligence in Kodam 2. His successor, Colonel Rudy Supriyatna, who held the post from August 1992 to February 1995, had previously served as Assistant for Intelligence to the Chief of Staff of Kodam 6.

86 In the years before his appointment as Commander of Korem 011, for example, Hamid had served as Assistant for Territorial Affairs in the important Greater Jakarta Regional Military Command. After his tour of duty in Aceh he served, among other posts, as Head of the Armed Forces Information Service (Kapuspen ABRI), Armed Forces Chief of Social and Political Affairs (Kasospol), and Minister of Home Affairs. 
Turning to Chiefs of Staff of Kodam 1, in the key years 1989 to 1993, we find again a pattern of domination by officers with intelligence and counter-insurgency backgrounds. The Chief of Staff from March 1989 to January 1991, Brigadier General R. Soerjadi, had served with the elite paracommando regiment, RPKAD, from 1965 to 1970, during which time it formed the backbone of the savage assault on real and alleged communists. Soerjadi's successor, the former Commander of Korem 011 Brigadier General Sofyan Effendi, who was Kodam 1 Chief of Staff from January 1991 to September 1992, had a strong counter-insurgency background, as noted above. ${ }^{87}$

A similar pattern is evident among Regional Military Commanders of Kodam 1. Major General R. Pramono, who held the post from June 1990 to April 1993-thus during the very worst of the violence in Aceh-had served as Assistant for Intelligence in Kodam 4 in Central Java in the early 1980s (in the lead-up to the Petrus killings) and as Kostrad Chief of Staff for the two years before his appointment as Commander of Kodam 1.88 His successor, Major General Pranowo, who held the position from April 1993 to Sept 1994, also had counter-insurgency experience. For two years immediately prior to his time in Aceh, he had been Chief of Staff of Kodam 8, based in Irian Jaya. Pranowo had also served as commander of the Presidential Security Force from 1985 to 1987, a post which would have brought him regularly into contact with the President and his immediate circle.

If the background of the key military officers in Aceh helps to explain the pattern of violence there in the early 1990s, a glimpse at the subsequent careers of these men leaves room for doubt that the immediate future will be much brighter. The most obvious cause for concern is that a number of the officers posted in Aceh during the worst of the violence subsequently moved swiftly up the military and political ladder, and by 1998 had assumed positions of considerable political power. They included Syarwan Hamid, who became Minister of Home Affairs in the Habibie government, and Zacky Anwar Makarim, who became Head of BIA in 1997. Another officer with Aceh experience still in a position of some influence in 1998 was Agum Gumelar, who in 1998 was Governor of the National Defence Institute (Lemhannas). All of these men were well placed to resist efforts to investigate military abuses in Aceh. They could, moreover, rely on the support of others in the military and political elite who had reason to fear that inquiries about Aceh might lead to revelations about wrongdoing in other parts of the country.

On the other hand, the career trajectory of a number of other figures responsible for the violence in Aceh provides reason for greater optimism. By late 1998, many of those in charge during the worst of the violence-Suharto, Prabowo Subianto, R. Pramono, $R$. Soerjadi, and Sofyan Effendi-had either been ousted or no longer held positions of real political or military power. This development arguably improved the prospects for

\footnotetext{
87 While Effendi's two immediate successors as Chief of Staff did not have counter-insurgency backgrounds, both were his classmates at the national military academy (AMN), having graduated together as Class 6 in 1965. No automatic inference can be drawn from this fact, but these collegial ties may well have encouraged Effendi's successors to maintain and pursue the approach he had helped to set in motion. In any case, the tradition of filling the Chief of Staff post with a counter-insurgency man was resumed in 1994, with the appointment of Brigadier General Agum Gumelar, who had served with Kopassus for some twenty-five years, two of them (1993-1994) as Commander.

88 Angkatan Bersenjata, August 9, 1988.
} 
a proper vetting of military responsibility in Aceh. Moreover, the fate of Prabowo and many of his closest allies, and the precipitous decline in the prestige of Kopassus in 1998, may help to ensure that terrorist methods will no longer be regarded as career enhancing options, a change that could lead to a general decline in state violence in the coming years.

\section{Conclusions}

I began by asking why Aceh was so unsettled, so rawan, under the New Order, and whether it is destined to remain that way in the post-Suharto era. The broad answer to the first question is that the violent conflict in Aceh after 1989 was not the inevitable consequence of primordial Acehnese sentiments, nor a manifestation of a venerable Acehnese tradition of resistance to outside authority or Islamic rectitude. Instead, I have argued that it was the unintended, but largely inevitable, consequence of certain characteristic policies and practices of the New Order state itself. The argument is not that the culture and traditions of the people of Aceh were of no importance in stimulating demands for independence there, or in generating the conflict that followed. Rather, I have tried to show how the policies and practices of the New Order regime, and the unique historical circumstances which shaped them, gave these incipient demands a much wider credibility than they might otherwise have had, and also ensured a rapid escalation from resolvable political disagreement to widespread violence and political conflict.

Both the Aceh Merdeka rebellions and the violence that followed appeared to be integrally linked to the New Order's management of the exploitation of Aceh's natural resources and the distribution of economic benefits, especially as these policies developed after the discovery of oil and LNG in the 1970s. Driven by a highly centralized system of decision-making, by its close association with foreign capital, and by the opportunities for public and private revenue generation that these arrangements provided, the New Order's own economic policy in Aceh kindled support for Aceh Merdeka among a broad cross-section of the population in the late 1970 s and 1980s. The regime's heightened efforts to ensure security in the area from the mid-1970s, largely through repressive means, paradoxically produced the opposite effect, generating still greater resentment and instability, and stimulating Aceh Merdeka's resurgence in 1989. Although Aceh Merdeka appeared to have been defeated militarily by the mid-1990s, the underlying economic and social grievances that made it popular had not been resolved by 1998. This was immediately evident when, with the fall of Suharto, Acehnese of diverse social backgrounds began to express their views openly again.

As fundamental and persistent as these grievances were in generating support for Aceh Merdeka, they did not appear to account for the unprecedented levels of violence that followed the movement's re-emergence in 1989 and persisted for nearly a decade thereafter. Aceh Merdeka was partly responsible for that development in the sense that its explicitly separatist objectives, bellicose language, resort to arms, and sense of timing seemed calculated to provoke a harsh government response. Nevertheless, the escalation and persistence of violence and instability after 1989, I have argued, was primarily the result of the specific doctrines and practices employed by the Indonesian 
armed forces in their efforts to quash the incipient rebellion-in particular the use of systematic terror and the forced mobilization of civilians as military auxiliaries.

In the short term, terror and "civil-military cooperation" worked rather well. By terrorizing the population, the military ensured that all but the most foolhardy would abandon the rebellion and remain silent about what they had witnessed. And by forcing the population to join in military and intelligence operations against members of their own communities, they divided those communities and effectively weakened the social base of the resistance. At the same time, however, Indonesian military policy and practice in Aceh produced a range of disastrous medium and long-term consequences. First, through the systematic use of terror, it generated levels of insecurity and political violence far greater than anything that ever was, or ever could have been, achieved by Aceh Merdeka itself. Second, by compelling civilians to participate in its intelligence and combat operations, it laid the foundation for bitter conflicts among Acehnese which surfaced in late 1998, and appeared likely to inhibit a return to peace. Third, by designating Aceh as a Military Operations Area for almost a decade, it may have fostered the emergence of a military mafia that could be expected to resist all efforts to change the status quo. Finally, by resorting to the use of provocation and terror against civilian populations, it stimulated a deep-seated anger among an ever-widening circle of Acehnese. As human rights activist Munir noted in August 1998, "The excesses committed during the military operation in Aceh have given birth to a seed of popular hatred toward the armed forces." ${ }^{89}$ That hatred, and the new cycle of violence it helped to generate in late 1998, were a depressing reminder that the legacy of the military strategy used in Aceh might survive long after its principal architect, Suharto, had left the scene. The failure of the Habibie government to address widespread concern about past military abuses, and its apparent inclination to pursue similar strategies in Aceh, further fueled popular anger and appeared likely to impede the prospects for peace.

The strategy and tactics employed in Aceh after 1990 were not the product of a rigid and unchanging Indonesian military doctrine. Rather they were shaped by the specific historical context within which both the rebellion and the response to it occurred. Three factors were especially important in facilitating the violence: an international and domestic political climate that together encouraged a sense of confidence and impunity among Indonesia's leaders in the use of terrorist methods; the existence of tensions within the Indonesian military, and in particular between the central command and local units deemed insufficiently loyal to the center; and finally, a pattern of domination of key military posts in Aceh by officers with close ties to the Palace and experience in counter-insurgency and intelligence.

To the extent that the methods used by the military in Aceh were shaped by unique historical conditions, it may be argued that changes in those conditions will alter the pattern of violence in the future. In this respect, a number of recent developments offer some grounds for optimism that Aceh, and other "trouble spots," may be spared a future of chronic violence. One potentially positive change, I have argued, is the decline in the power and prestige of Kopassus, and of other units specializing in counter-insurgency and terror. Another is the dismissal of Prabowo, and the fact that

${ }^{89}$ Tajuk, August 20, 1998. 
the careers of many of the key figures responsible for military operations in Aceh have gone nowhere. Although they must be set against the Habibie government's strong disinclination to investigate and punish past abuses, these developments may nevertheless serve to weaken the propensity for the use of official violence in Aceh and elsewhere in the future.

Perhaps the greatest reason for optimism, however, lies in the remarkable changes in the domestic and international political climate that have come with the collapse of the New Order. Within a few months of the Suharto regime's demise the mysterious killings, the rapes, the mass graves, and a litany of other crimes committed by the armed forces in Aceh over almost a decade became the focus of wide-ranging public scrutiny and debate. Key members of the international community, so long complicit in hiding these and other New Order crimes, appeared ready to support moves toward genuine democratization. Notwithstanding serious doubts about the sincerity of the Habibie government's commitment to reform, these shifts appeared to offer a rare opportunity to pursue investigations into past military wrong-doing, to prosecute the authorities responsible, and thereby to break the cycle of impunity that had for so long encouraged abuses to continue.

An important implication of these recent developments, and of the historical evidence presented in this paper, is that continued conflict in Aceh, and perhaps in other "trouble spots" as well, is by no means inevitable. On the contrary, if I am right in locating the problem of instability and violence in the distinctive policies and practices of the late New Order state, and in the particular historical context within which they were played out, then a change in those policies and in that context could conceivably bring an end to the violence, and perhaps even to demands for independence. The evidence also suggests that national disintegration will not be the automatic result of an end to authoritarian rule in Indonesia. In fact, I think it can be argued that, far from jeopardizing the political future of the country, a shift toward a less authoritarian political system-and one which is less wedded to the use of terrormay provide the best possible guarantee of its continued unity and viability.

Appendix 1: Key military figures in Aceh, 1988-1995

Regional Military Commanders - Kodam 1

12 Aug $88-9$ Jun 90

9 Jun $90-1$ Apr 93

1 Apr $93-1$ Sep 94

1 Sep $94-2$ Aug 95

Chiefs of Staff - Kodam I

22 Mar 89 -Jan 91

Jan $91-10 \operatorname{Sep} 92$

10 Sep $92-8$ Jan 94

8 Jan $94-23$ Sep 94

23 Sep $94-1$ Mar 96
Maj. Gen Joko Pramono

Maj. Gen. R. Pramono

Maj. Gen. A. Pranowo

Maj. Gen. Arie Kumaat

Brig. Gen. Soerjadi

Brig. Gen. Sofyan Effendi

Brig. Gen. R. Karyono

Brig. Gen Makmun Rasyid

Brig. Gen. Agum Gumelar 
156 Geoffrey Robinson

Military Resort Commanders - Korem 011/Lilawangsa

? - 12 Aug 89

12 Aug $89-$ Jan 91

Jan 91 - Dec 92

Dec 92 - 19 Apr 94

19 Apr $94-6$ Mar 95
Col. H.M. Ali Hanafiah

Col. Sofyan Effendi

Col. Syarwan Hamid

Col. Sridono

Col. Djoko Subroto

Military Resort Commanders - Korem 012/Teuku Umar

? - 4 April 89

4 April 89 - 10 Aug 92

20 Aug 92 - 11 Feb 95

11 Feb 95 - ?
Col. Soehardjono

Col. Muhammad Chan

Col. Rudy Supriyatna

Col. Ahmad Yourda Adnan 